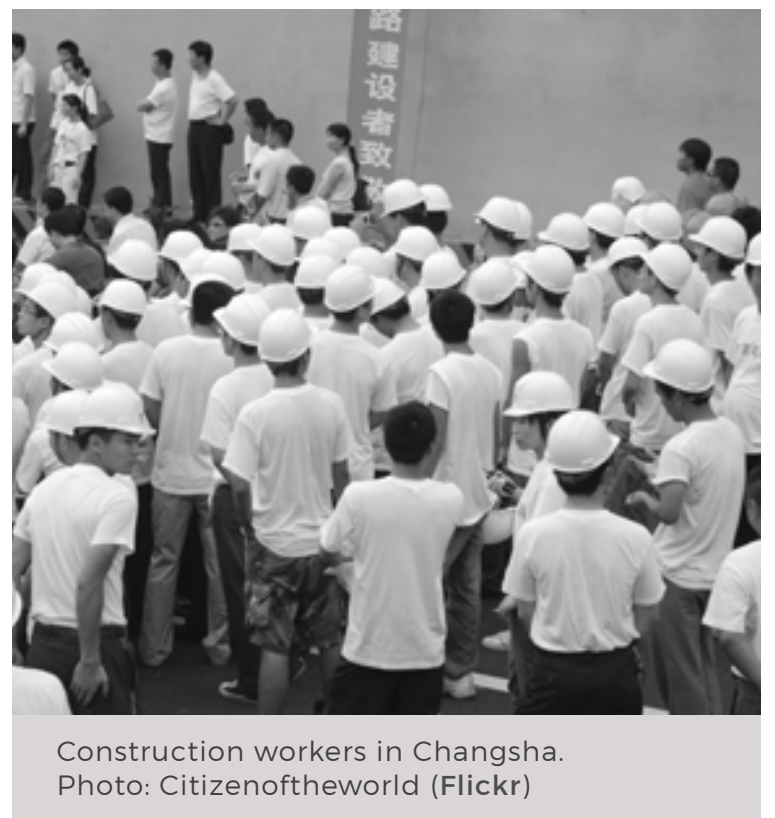

\section{Collective Bargaining in China is Dead: The Situation is Excellent}

\section{Eli Friedman}

As the Chinese government under Xi Jinping has turned in a markedly anti-worker direction, attempts to establish a genuine collective bargaining system in China have been smothered. If collective bargaining is dead, what might Chinese workers and their allies advocate? The time might be ripe to shift our focus to a demand for a rapid expansion of universal social services, not least for a universal basic income.
For many years reform-oriented labour activists and scholars working in China have seen collective bargaining as the cure for the country's severe labour problems. The logic underlying this was often unstated, but straightforward: collective bargaining was crucial for twentieth century labour movements in capitalist countries in giving workers a voice and creating a more equitable social distribution of wealth. With growing levels of labour unrest in China over the past twenty years, collective bargaining seemed like a logical next step. Hopeful reformers-both within the official unions as well as labour NGO activists and academicsenvisioned rationalised, legalised bargaining between labour and capital as a central pillar in the construction of a more just workplace and society.

The challenges to institutionalising a robust collective bargaining system in the People's Republic of China (PRC) have always been profound. Fundamental to labour relations theory is that collective bargaining rights must be accompanied by the right to strike and freedom of association-capital has no reason to take workers seriously without labour possessing some coercive power. But independent unions have long been an anathema to the Communist Party. From the Lai Ruoyu debacle of the 1950s to the crushing of the Beijing Workers Autonomous Federation in 1989, the Party has made it clear time and again that independent worker organisations are forbidden. Although workers have never enjoyed the right to strike in practice, the right was formally included in the Chinese constitutions of 1975 and 1978. It was Deng Xiaoping who removed it from the constitution just as private capital began pouring into China in the early 1980s.

\section{Working Within the System}

Nonetheless, with no signs of articulated worker movements since 1989, many well- 
intentioned people thought it was worth trying to advance worker rights within the system. Especially from the mid 2000s on, academics (myself included) launched research projects, NGOs held training sessions, and foreign unions engaged with the All-China Federation of Trade Unions (ACFTU). Many assumed that the state would eventually decide that worker insurgency was exacting too high a cost, and that serious labour reforms were therefore necessary. And indeed, beginning in the late 2000s the ACFTU made collective negotiations (xieshang)-rather than the more antagonistic sounding 'bargaining' (tanpan)-a high priority, investing time and resources into expanding the coverage of collective contracts.

At its best, collective bargaining in China has been woefully inadequate. The state and the ACFTU have been very cautious about controlling workers' aspirations, and have insisted on the fundamental harmony of interests between labour and capital. Experiments with bargaining have been almost exclusively restricted to single enterprises, thereby preventing workers from constituting cross-workplace ties. The overwhelming majority of collective contracts are formulaic: actual bargaining rarely occurs, and enforcement is largely nonexistent. The few shining examples where employers have made real compromises during collective bargaining have followed autonomously organised wildcat strikes. The best-known case is the 2010 strike from a Honda transmission plant in Guangdong province, which resulted in major wage gains as well as an (ultimately unsuccessful) effort to reform the enterprise union. It is not coincidental that substantive worker-led bargaining is much more likely in Japanese or American firms, where the state must be cautious not to inflame patriotic sentiments. State-sanctioned economic nationalism is a shaky foundation for a robust collective bargaining system.

\section{The Death of Collective Bargaining under $\mathbf{X} \mathbf{i}$}

Even these timid efforts have been smothered in recent years, as the central government has turned in a markedly antiworker direction under $\mathrm{Xi}$ Jinping. There was a brief moment in 2010 when discussion about the right to strike emerged from hushed whispers into the public discourse. But this opening was ephemeral, and union reformers in Guangdong who had pushed gentle reforms in the mid-late 2000s were replaced with typical Party apparatchiks. The country's preeminent centre for labour studies at Sun Yatsen University in Guangzhou was shuttered. The academic study of employment has now been left almost entirely to business schools, as the government has stymied further expansion of labour relations programs. Labour NGOs in Guangzhou were subjected to a brutal crackdown in December 2015, with the government specifically targeting those groups that had been helping workers to engage in collective negotiations to resolve strikes. And the ACFTU has seemingly given up on advancing collective negotiations altogether. The Chairman of the ACFTU Li Jianguo does not even mention the term in his speeches anymore. Under the 'work developments' section of the ACFTU's website, a lonely single report on collective contracts for the entirety of 2016 is a stark indication that the union has almost totally forsaken this agenda.

Collective bargaining is not dead in the sense that it will disappear from China's labour-capital relations. It is almost certain that official unions will continue to pursue bargaining in its current vacuous, bureaucratic, and worker-exclusionary form. Collective contracts will continue to be signed, tabulated, and then hidden from view from workers. Somewhat less pessimistically, workers will continue to force management to bargain with the collective via wildcat 
strikes. This latter form will still be an important means by which workers can attempt to ensure their most basic rights, and these efforts are absolutely worth supporting. But collective bargaining is dead as a political aim. It is not going to be the cornerstone of twentieth century-style class compromise in China, it is not generative of worker power, and it certainly does not herald broader social transformation. To the extent that legal bargaining does develop, it will be as a mechanism for the state to deprive workers of autonomous power.

What then might Chinese workers and allied intellectuals and activists aim for? At the risk of stating the obvious, the working class needs more power. The question is, how to foster proletarian power in the face of a highly competent authoritarian state that views organised workers as an existential threat? In the absence of independent organisations, the only option is an intensification of already widespread worker insurgency. The more wildcat strikes, mass direct action, and worker riots, the more the state and capital will be forced to take worker grievances seriously. Of course such forms of collective action come at great risk for workers, and many have already paid a high price. In any particular case, the risks may certainly outweigh the benefits. But in the aggregate, expansive unrest is just what the working class needs. With the institutions firmly oriented towards advancing the inter-related goals of state domination and exploitation by capital, disruption on a large scale is the only chance workers have of forcing change. Ungovernability will be the necessary prelude to any institutional reform worthy of the name.

\section{The Quest for Universal Basic Income}

Let's now imagine a scenario-a fantastic one, admittedly, but one for which we should be prepared: worker unrest hits some inflection point, and the state comes begging for compromise. If collective bargaining is dead on arrival, what might Chinese workers and their allies advocate? The time has come to shift our focus to a demand for a rapid expansion of universal social services, not least of which should be universal basic income (UBI).

UBI has been hotly debated in North America and Europe in recent years. There are numerous excellent accounts of various ways of structuring UBI, which I cannot rehash in detail here. But the fundamental idea is that all members within some given political jurisdiction receive a certain income by virtue of their citizenship-there are no means tests, and everyone receives the same amount regardless of employment status or existing wealth.

Perhaps the most frequently cited reason for implementing UBI is that technological development is increasing productivity while undermining the stability of jobs. A somewhat more expansive version of this argument recognises the diverse ways that people contribute to capital accumulation outside of wage labour-if the traditional wage is an increasingly unreliable measure of value production, perhaps it should be abandoned altogether. Another important point is that UBI would have the advantage of freeing up time for more socially constructive activities. Liberated from the daily struggle for survival, people will have the space to do what they will-including engaging in politics. In this sense, UBI is not merely an end in itself but also a means for developing the political energies of the dominated.

UBI is by no means a panacea, and at worst it could be a Trojan horse for austerity. Many conservatives have come to embrace UBI, as they see it as an efficient replacement for all other social programs. An additional concern is that it is unlikely that elites will endow society with the right kind of UBI in the absence of vigorous, organised demands 
from below. A technocratic approach will likely serve the interests of elites, or will be unenforceable.

A few exceptions notwithstanding, UBI has aroused little discussion within China. There are a variety of reasons for this, not least of which has been thirty years of nearly unbroken economic development and job growth. Industries such as manufacturing and construction have absorbed huge volumes of labour, and automation has only just begun chipping away at this growth in employment. Ideologically, UBI has resonances with the state socialist 'iron rice bowl', and runs counter to dominant meritocratic discourses that valorise hard work. Advocates of UBI would likely encounter repression, as the state is constitutionally opposed to any politics that could articulate the aspirations of a broad constituency. Given all of this, UBI has not yet gained widespread currency in China, and workers have not put it forward as a demand.

Nonetheless, the moment seems ripe to raise the topic for debate. Economic growth is slowing, automation is accelerating, and greater numbers of people are dependent on highly informal, contingent, and irregular forms of work to survive. Minimum wages increased significantly from 2010 until last year, but have more recently been frozen in many provinces. The growing informal workforce does not enjoy minimum wage rights, and even formal workers with a labour contract often have to protest just to have basic laws enforced. Furthermore, the minimum wage has never been a liveable wage, particularly for migrant workers excluded from state-subsidised health care, education, and housing. The contradiction between China's highly uneven economic geography and localised system of social welfare provision on the one side, and its unified national labour market on the other, is only likely to intensify. UBI cannot be realised without widespread working class support and mobilisation-now is the time to plant the seed.

\section{Crucial Questions}

There are important details that would need to be worked out for UBI to be effectively implemented, especially in a place as large and complex as China. Crucial questions about how to fund such a program, how much citizens would receive, and the administrative arrangements could determine success or failure. But even in advance of having a perfectly worked out plan, the demand serves an important political purpose: it proposes that all humans have a right to subsist, irrespective of their utility to capital. Particularly given China's highly fractured welfare regime, the demand could serve to unify people across region, ethnicity, and hukou status. If linked to demands for universalising other forms of social protection such as healthcare, education, and housing, it could lay the foundation for meaningful human autonomy from the dictates of the market.

Is the demand for UBI in China utopian? Perhaps. But based on the past two decades of experience, we know for a fact that collective bargaining is a chimera. As China's wealth and social inequalities yawn ever wider, factories relocate to cheaper locales, automation expunges workers from the labour process, and the old state socialist institutions continue to rot in irrelevance, it is time to change tack. The death of collective bargaining may yet be a gift to China's workers.

\section{Eli Friedman}

Eli Friedman is an Assistant Professor of International and Comparative Labour at Cornell University and the author of Insurgency Trap: Labor Politics in Postsocialist China (Cornell University Press, 2014). 